\title{
K POSTHUMÁNNEMU ČLOVEKU PROSTREDNÍCTVOM EDITOVANIA GÉNOV PRE KOGNITÍVNE SCHOPNOSTI
}

PETER SÝKORA, Katedra filozofie a aplikovanej filozofie, Centrum pre bioetiku, Filozofická fakulta Univerzity sv. Cyrila a Metoda v Trnave, Trnava, SR

SÝKORA, P.: Towards the Posthuman Through the Editing of Genes for Cognitive Capabilities

FILOZOFIA, 74, 2019, No 7, pp. $511-529$

\begin{abstract}
The recent, extremely dynamic development of modern methods of biotechnological manipulation of genes, including human germline genes, presents new challenges to philosophers and especially bioethicists with unprecedented urgency. Until recently, many of these issues have been the subject of science fiction, and neither biologists nor bioethicists have expected them to be occuring now rather than in the distant future. It can be assumed that germline gene editing (together with progress in understanding of the human genome) will bring in the near future empirical knowledge, which will put the current philosophical concepts of human nature (based primarily on the speculative philosophical tradition) to the test.
\end{abstract}

Keywords: Germline gene editing - Cognitive enhancement - Human nature Posthumanism

\section{Úvod}

„Francúzsky encyklopedista Diderot pred dvesto rokmi opísal vironickej vidine budúcnosti nazvanej D'Alembertov sen, ako sa jedného dňa budú umelo pestovat' l'udské embryá s vopred určeným dedičným poslaním. [...] Dnes sa už táto predstava nezdá celkom fantastická a niektorí biológovia sa nazdávajú, že sa môže uskutočnit’ najneskôr do konca storočia. [...] Mám podozrenie, že bezprostredná reakcia mnohých l’udí na takéto predpovede je nasledovná: bud' ich pokladajú jednoducho za nemožné, alebo ich uskutočnenie kladú tak d'aleko do budúcnosti, že pre dnešných l’udí nemôžu mat' nijaký praktický význam. “

G. R. Taylor: Biologická časovaná bomba (1971, orig. 1968, 15 - 19)

Prestížny vedecký časopis Nature priniesol 14. marca 2019 spoločné vyhlásenie viacerých renomovaných biológov a bioetikov z rôznych krajín, v ktorom vyzývajú ku globálnemu (dočasnému) pozastaveniu (moratóriu) pokusov, ktorými by sa vytvárali dedične geneticky editované deti. Toto pozastavenie by malo „umožnit’ diskusie 
o technických, vedeckých, medicínskych, spoločenských, etických a morálnych záležitostiach, ktoré musia byt' posúdené, skôr ako bude editovanie zárodočnej línie povolené. Toto obdobie by malo poskytnút' čas, aby bol vytvorený medzinárodný rámec" (Lander et al. 2019, 165). Toto moratórium sa nevzt’ahuje na výskum (ak nezahŕňa transfer embryí do maternice) a nevzt’ahuje sa ani na intervenciu do génov somatických buniek.

Vedci k takýmto vyhláseniam pristupujú len v mimoriadnych situáciách, ked' sami s vel'kou zodpovednost'ou voči spoločnosti pocit'ujú obavy z neželaných dôsledkov a rizík spojených s ich vedeckými objavmi. Toto vyhlásenie našlo podporu v dôležitých vedeckých inštitúciách a organizáciách, akými sú Národné ústavy zdravia (NIH) v USA a Európska spoločnost' pre l'udskú reprodukciu a embryológiu (ESHRE).

Výzva na dočasné moratórium ohl'adne editovania l'udských zárodočných génov je priamou reakciou na nedávne šokujúce oznámenie čínskeho vedca He Jiankuia z Južnej vedecko-technologickej univerzity v Shenzhene (The Southern University of Science and Technology, Shenzhen). ${ }^{1}$ He Jiankui oznámil prostredníctvom sociálnych médií v nedel'u 25. novembra 2018, ${ }^{2}$ že vytvoril prvých l'udí s dedične upravenými génmi (Regalado 2018). Ide o dvojičky Lulu a Nana (pseudonymy), ktoré sa narodili z génovo editovaných raných in vitro embryí. Tento rok sa má narodit' tretie takto geneticky dizajnované diet’a. He Jiankui použil pre potreby tejto genetickej manipulácie novú, mimoriadne efektívnu technológiu tzv. editovania génov, známu pod skratkou CRISPR/Cas9. ${ }^{3}$ Ciel'om tejto ,génovej chirurgie“ (gene surgery), ako svoj postup označil sám He Jiankui, bolo vystrihnút' z genómu l'udských embryí gén CCR5 kódujúci bunkový receptor pre vírus HIV, vd'aka čomu by l'udský jedinec, ktorý sa vyvinie z takéhoto embrya, stal odolným voči infekcii vírusom HIV. Ked’že išlo o pozmenenie genetickej informácie v zárodočnej línii buniek (germline cells), táto genetická zmena je dedičná a bude sa prenášat' na všetky nasledujúce generácie.

Prvýkrát v dejinách l'udstva sa tak stalo to, čo už dávnejšie predpovedali tvorcovia vedeckej fantastiky spolu s vedcami, filozofmi a bioetikmi, teda že človek začne priamo dizajnovat' l'udský genóm a cielene menit' svoju vlastnú genetickú výbavu. Dôraz sa tu kladie na slovíčko ,priamo“, pretože ,nepriamo“ genetickú výbavu živých organizmov vrátane človeka doteraz po milióny rokov dizajnovala príroda prostredníctvom kombinácie mutácií a prírodného výberu. Až pomerne nedávno v evo-

\footnotetext{
${ }^{1}$ Južná vedecko-technologická univerzita v Shenzhene prepustila He Jiankuiho zo svojich radov, ked' sa dozvedela o jeho experimentoch a začali ho vyšetrovat' aj čínske štátne orgány.

${ }^{2}$ The He Lab: Why We Chose HIV and CCR5 First. Zverejnené 25. 11. 2018. Dostupné na https://www.youtube.com/watch? $\mathrm{v}=$ aezxaOn0efE.

${ }^{3} \mathrm{CRISPR}=$ skratka $\mathrm{z}$ angl. clustered regularly interspaced short palindromic repeats (nahromadené pravidelne rozmiestnené krátke palindromické opakovania). Ide o sekvencie DNA. Cas9 = skratka z angl. značí CRISPR-associated protein 9.
} 
lučnej histórii l'udského rodu sa k prírode a jej nepriamemu ovplyvňovaniu genetickej výbavy budúcich generácií pridal aj človek, a to prostredníctvom kultivácie a domestifikácie, teda umelým výberom rastlín a zvierat, a nakoniec aj spornými snahami aplikovat' tento postup na seba samého (klasická eugenika).

Problematike genetického kognitívneho vylepšovania človeka sme sa v minulosti už venovali v kontexte celkovej problematiky vylepšovania (Sýkora, Matějková 2011). Podrobnejšie sme sa na inom mieste venovali argumentácii opierajúcej sa o teologickú a teleologickú perspektívu, podl’a ktorej genetické manipulovanie s ludským genómom ohrozuje l'udskú prirodzenost', a tým ohrozuje aj najvlastnejší zmysel l'udského života (Sýkora 2014). Taktiež sme sa v predchádzajúcich prácach venovali aj mimoriadne dôležitej otázke rizikovosti použitia technológí́ editovania génov u človeka (Sýkora 2015, 2018).

$\mathrm{V}$ tejto štúdii sa chceme pozriet' na problém editovania génov z perspektívy polstoročnej histórie technológií manipulovania s génmi organizmov, konfrontovanej s predpoved’ami z konca šest'desiatych rokov minulého storočia $\mathrm{v}$ dnes neprávom opomínanej knižke Biologická časovaná bomba. Nazdávame sa, že v situácii, v akej sa nachádza teraz editovanie génov, môže byt' poučné pozriet' sa na dávnejšie predpovede revolučného vývoja biológie a biotechnológií. Ktorá z predpovedí sa naplnila, ktorá nie a prečo. Možno nám takéto poznanie pomôže presnejšie predpovedat' vývoj modernej biomedicíny a technológií editovania génov na d’alšie polstoročie. V tejto štúdii zdôrazníme, v čom tkvie rozdiel medzi klasickými technológiami génového inžinierstva, ktoré viedli $\mathrm{k}$ tvorbe geneticky modifikovaných organizmov (GMO) a technológiou editovania génov, ktorá viedla $\mathrm{k}$ vytvoreniu prvých geneticky modifikovaných l'udí. Zameriame sa na to, prečo je tento rozdiel dôležitý pre úvahy o trans-a posthumanizme v súvislosti s hladaním odpovede na otázku o budúcej existencii l'udstva, o ktorej sa bude rozhodovat' najbližších pät'desiatich rokov. Ciel'om tejto štúdie je podporit' našu tézu, že vznik posthumánneho človeka môžeme skôr očakávat' ako výsledok cieleného génového dizajnovania v oblasti biológie, než ako výsledok tzv. uploadovania mysle do nebiologického média v oblasti informačno-komunikačných technológií, a preto je podl'a nášho názoru vel'mi dôležité nasmerovat' pozornost' diskurzu o posthumanizme týmto smerom.

\section{Objavy technológií manipulovania s génmi sú výsledkom základného výskumu}

Začnime našu exkurziu do histórie génových manipulácií pripomenutím pozoruhodnej, no dnes v diskusiách o editovaní génov opomínanej vedecko-populárnej knižky britského žurnalistu G. R. Taylora (1911 - 1981) Biologická časovaná bomba z roku 1968. Išlo o vôbec prvú knihu, ktorá širokú verejnost' upozornila na skutočnost', že biológia sa ocitla $\mathrm{v}$ počiatočnom štádiu revolučnej premeny, ktorá bude mat' hlboký 
celospoločenské dôsledky. Kniha zapôsobila na čitatel’ov šokujúco, čo bol bezpochyby jeden z jej cielov, a stala sa bestsellerom, čím sa naplnil aj d’alší zámer - oslovit' čo najširšiu verejnost'. A prinajmenšom ešte $v$ jednej veci spomenutá kniha splnila svoj ciel'. Mala vyvolat' apel na spoločnost', aby začala zriad'ovat' komisie, ktoré sa budú zaoberat' širšími etickými otázkami súvisiacimi s biologickou revolúciou, ako je oblast' lekárskej etiky (Taylor 1971, 265). Taylor tiež v knižke navrhoval, aby sa na univerzitách zakladali pracoviská, ktoré sa budú zaoberat' budúcnost'ou a budú skúmat' možné právne, ekonomické a sociálne dôsledky biologickej revolúcie. ${ }^{4}$

Vieme, že tieto výzvy nezostali bez odozvy. Aký podiel na tom mala sama Taylorova knižka a aké boli prvé prejavy predpovedanej biologickej revolúcie, nie je dôležité. Faktom je, že postupne začali vo svete vznikat' akademické pracoviská - inštitúty, katedry a centrá pre bioetiku. Prvým takýmto pracoviskom sa stal The Hastings Center v štáte New York, založený ešte v roku 1969. Prvou celoštátnou bioetickou komisiou na svete sa stal Národný poradný výbor pre etiku vied o živote a zdraví (Comité Consultatif National d'Ethique pour les sciences de la vie et de la santé), ustanovený francúzskym prezidentom Françoisom Mitterrandom v roku 1983.

Podla Taylora biologická revolúcia ovplyvní naše životy ovel’a hlbšie ako industriálna revolúcia devätnásteho storočia a technologická revolúcia dvadsiateho storočia. ${ }^{5}$ Koncom šest'desiatych rokov vedelo o tejto revolučnej premene biológie, ktorú v tom čase verejnost' ešte vždy pokladala pre spoločnost' za nezaujímavú vedu, len niekol'ko vedcov. Biológovia boli na rozdiel od fyzikov - ktorí prišli s prevratnými objavmi o podstate hmoty a vesmíru, pričom tie viedli $\mathrm{k}$ technologickým využitiam takého rozsahu, že sa v ohrození ocitla existencia l’udstva ako taká -, vcelku nezaujímaví podivíni, ktorí, povedané slovami Taylora, sa venujú hlavne klasifikovaniu organizmov, botanizovaniu, sledovaniu st’ahovania vtákov, pitvaniu žiab či štúdiu včiel (Taylor 1971, 15). Taylorova kniha pootvorila dvere biologických laboratórií a zaoberala sa témami, ktoré sa $\mathrm{v}$ šest'desiatych a sedemdesiatych rokoch mohli širokej verejnosti javit' ako čistá fantázia, $v$ lepšom prípade otázka d’alekej budúcnosti: deti zo skúmavky - klonovanie - transplantácie - ovládnutie nálad - regenerácie orgánov - vstrekovanie pamäti. Dnes vieme, že nešlo o fantáziu a mnohé z neuveritel'ne znejúcich predpovedí z Taylorovej knihy sa naplnili.

Avšak nie celkom tak, ako si to Taylor predstavoval, opierajúc sa o informácie vedcov, s ktorými pri príprave knihy spolupracoval. Jednou z vecí, v ktorej sa najviac

\footnotetext{
${ }^{4}$ A nepochybne tiež inšpirovala v dobe svojho vydania mnohých mladých l'udí, aby sa začali venovat' modernej biológii, prípadne bioetike. Autor tejto štúdie je jedným z nich.

${ }^{5}$ Nezabúdajme, že Taylor písal svoju knižku koncom šest’desiatych rokov minulého storočia, ešte pred nástupom informačno-komunikačných technológii v tretej tretine dvadsiateho storočia, teda pred érou osobných počítačov, mobilov a internetu.
} 
pomýlil pri odhade doby realizácie, je génové inžinierstvo, špeciálne jeho aplikovanie na človeka. Taylor svoje predpovede rozvoja biologickej revolúcie rozdelil na tri fázy. Pre prvú (okolo roku 1975) predpovedal napríklad uskutočňovanie transplantácie orgánov a údov alebo umelé oplodñovanie v skúmavke, pre druhú (okolo roku 2000) napríklad klonovanie živočíchov, regeneráciu orgánov, chiméry človek-zviera, a až pre tretiu fázu (po roku 2000) predpovedal okrem klonovania l'udí aj kontrolu starnutia či neobmedzený odklad smrti a syntézu zložitých živých organizmov vrátane „vkladania a ničenia génov“.

Dnes, takmer dve desat'ročia po roku 2000, sme ešte vždy vel'mi d'aleko od kontroly starnutia, ako aj od syntézy zložitých organizmov. Klonovanie l’udí je síce technologicky možné, ale eticky a legislatívne neprípustné. Na druhej strane „vkladanie a ničenie génov" sa začalo ovel’a skôr, ako to Taylor predpovedal. Pokúsme sa teraz odpovedat' na otázku, prečo Taylor nesprávne predpovedal používanie „génovej mikrochirurgie" v ovel'a neskoršom čase, ako sa to nakoniec stalo.

Podla nášho názoru je táto Taylorova mylná predikcia krásnym potvrdením skutočnosti, známej aj z prípadov nástupu iných revolučných technológií, a síce že objav revolučných technológií sa nedá predpovedat', preto je prekvapivý. V prípade manipulácie génov to platí dvojnásobne - objav génového inžinierstva a techník rekombinantnej DNA v sedemdesiatych rokoch minulého storočia, rovnako ako nedávny objav génového editovania pomocou revolučnej technológie CRISPR/Cas9 v roku 2012 bol prekvapivý a vopred nebol predpovedaný (Ledford 2015). Taylor vo svojej Biologickej časovanej bombe vcelku dobre odhadol nástup viacerých biologických techník a technológí, tak prečo sa $\mathrm{v}$ prípade techník manipulácie $\mathrm{s}$ génmi tak výrazne zmýlil? Treba hned' na začiatku povedat', že tu nešlo o osobné názory laika (žurnalistu), pretože Taylor sa vo svojich predikciách opieral o názory vedeckej komunity. Inými slovami Taylor sa pomýlil, pretože ani sama vedecká komunita neočakávala také skoré použitie génových manipulácií, pretože na základe vtedy známeho biologického poznania si nevedela dost' dobre predstavit' (až na niekol'ko málo vedcov ako E. Tatum a J. Lederberg), ako by sa také mikrochirurgické manipulácie s génmi dali v praxi realizovat'.

Taylor napr. uvádza dobové špekulácie, ktoré už dnes pôsobia absurdne: „Mikrochirurgia DNA by sa možno dala robit' fyzikálnymi metódami - úzkymi lúčmi žiarenia (pravdepodobne laserovým svetlom alebo pulzmi X-lúčov) by sa mohla rozrezat' molekula DNA na vhodných miestach, alebo by sa mohli vyrezat' malé úseky, aby sa odstránili niektoré defekty“ (Taylor 1971, 199).

Historickou skutočnost'ou je, že k objavu obidvoch revolučných genetických technológií, ako technológie génového inžinierstva, tak aj technológie CRISPR/Cas9 editovania génov viedol mnohoročný základný výskum, ktorý vôbec nemal za ciel' 
objavit' nové biotechnológie, ale pochopit' prírodou vytvorené molekulárne mechanizmy, ako sa baktérie bránia proti napadnutiu vírusmi.

\section{V čom je podstatný rozdiel medzi génovým inžinierstvom a editovaním génov?}

Bežne sa editovanie génov pokladá za obdobu génového inžinierstva. Odporcovia vytvárania geneticky modifikovaných organizmov (GMO) považujú technológiu CRISPR/Cas9 za extrémne účinnú formu génového inžinierstva, a preto aj za ovel'a nebezpečnejšiu, ako je tradičné génové inžinierstvo. Avšak editovanie génov nie je obdobou vytvárania rekombinantnej DNA, čo je prvý krok génového inžinierstva. Prostredníctvom rekombinantnej DNA boli vytvorené GMO mikróby, rastliny či zvieratá, kde do jedného biologického druhu bol prenesený gén z iného biologického druhu. Napríklad do baktérie bol vložený l’udský gén, do rastliny gén baktérie, do králika alebo akváriových rybičiek gén medúzy a podobne. V prípade editovania génov ide o priame editovanie genetickej informácie, ktoré je vel'mi po-dobné editovaniu textu v počítači pomocou Microsoft Wordu. Z tohto dôvodu americká agentúra FDA (Food and Drug Administration), ktorá má na starosti kontrolu vytvárania GMO, spočiatku odmietla posudzovat' génovo editované organizmy, pretože platná legislatíva definovala GMO prostredníctvom prenosu cudzej DNA, a u týchto organizmov k žiadnemu takémuto prenosu nedošlo (Ledford 2015).

Popíšeme preto stručne princípy fungovania obidvoch systémov. Nástroje molekulárnej biológie označované súhrnne ako génové inžinierstvo sa začali vyvíjat' od polovice sedemdesiatych rokov minulého storočia. Okamžite sa začali využívat' v základnom i aplikovanom biologickom a biomedicínskom výskume, ale takmer súčasne aj v moderných biotechnológiách. A taktiež okamžite vyvolali obavy z možného nesprávneho použitia, prípadne zneužitia - najprv u odbornej verejnosti, potom aj v spoločnosti.

Podstatou metód génového inžinierstva je vytváranie rekombinantnej DNA v podmienkach in vitro. Najprv sa DNA izolovaná z rôznych organizmov pomocou špeciálnych enzýmov (tzv. reštrikčných endonukleáz) postrihá na fragmenty DNA. Tieto fragmenty majú tzv. lepkavé konce. To znamená, že fragmenty postrihané tým istým reštrikčným enzýmom sa v roztoku samovol'ne pospájajú do celkov bez ohl'adu na to, z ktorého organizmu pochádzajú. Týmto mechanizmom sa fragmenty akejkol'vek DNA tiež môžu včlenit' do malinkých autonómnych molekúl DNA, ktoré slúžia ako prenášače cudzej DNA do buniek. Prenášače, vektory sú vytvorené z upravenej DNA vírusov alebo plazmidov. Pomocou vektorov môže byt' dopravená cudzia DNA do baktérií, buniek rastlín, zvierat alebo l'udí. Táto cudzia DNA sa v bunke bud' inkorporuje v jadre do chromozómu a stane sa jeho integrálnou súčast'ou, alebo sa bude vyskytovat' v cytoplazme. Spôsob, ked' sa cudzia DNA integruje do chromozómu, sa 
využíva pri tvorbe transgénových organizmov. Vtedy sa cudzí gén vovedie do oplodneného vajíčka (zygoty), kde sa integruje do chromozómu a stane sa novou súčast’ou genetickej výbavy organizmu. Navyše dedičnou súčast'ou, pretože sa bude integrovaný $\mathrm{v}$ chromozóme prenášat' $\mathrm{z}$ generácie na generáciu. To je prípad vytvárania transgénových rastlín a zvierat.

Tento postup sa dá využit' aj na tzv. génovú terapiu. V takom prípade je cudzím génom izolovaný zdravý, nepoškodený, nezmutovaný gén, ktorý je pomocou vektora vovedený do buniek s poškodeným, a preto nefunkčným génom. To sa môže uskutočnit' ako ex vivo (v skúmavkách na izolovaných kmeňových bunkách kostnej drene) alebo in vivo (zdravý gén naviazaný na vektor sa injikuje priamo do organizmu). $\mathrm{Na}$ to, aby zdravý gén nahradil chýbajúcu funkciu poškodeného génu v bunke, sa môže, ale aj nemusí integrovat' do chromozómu. Dôležité je, aby v bunke správne fungoval.

Vel'kou nevýhodou genetického inžinierstva je, že je málo efektívne. Reštrikčné enzýmy strihajú DNA na fragmenty viac-menej náhodne, nie tam, kde by sme potrebovali, ale tam, kde sa vyskytuje krátka špecifická sekvencia písmen genetickej abecedy. A podobne je to aj s integrovaním cudzej DNA do chromozómu pri tvorbe transgénových organizmov. Musí preto nasledovat' časovo náročný proces selekcie, aby boli z obrovskej plejády neúspešných, viac-menej náhodných včlenení cudzej DNA vybraní jedinci, u ktorých sa cudzia DNA trafila a v chromozóme integrovala na želané miesto. Čím sú organizmy zložitejšie, tým je tento proces technicky aj časovo náročnejší, pretože sa musí udiat' na vel'kej populácii jedincov, aby bolo možné z väčšiny neúspešných zásahov vybrat' tých niekol'ko úspešných. Už len z tohto dôvodu odborníci vedeli, že vytvorenie transgénových l’udí metódami génového inžinierstva je prakticky nemožné (Capecchi 2000).

Naproti tomu metóda editovania génov, a z nich najmä CRISPR/Cas9, ktorá bola prvýkrát použitá v roku 2013, predstavuje oproti klasickému génovému inžinierstvu technologickú revolúciu, pretože je to technológia rádovo efektívnejšia a neporovnatel'ne presnejšia. Navyše jednoducho uskutočnitel'ná, a čo je nezanedbatel'ný faktor, aj finančne nenáročná.

Systém známy ako CRISPR/Cas9 je komplexom syntetickej molekuly RNA a molekuly enzýmu Cas9, ktorý je v podmienkach in vitro aj in vivo schopný prestrihnút' DNA (jej obidve vlákna) na špecifickom mieste s presnost'ou na jedno písmeno genetickej abecedy. Strihacím enzýmom je endonukleáza Cas9. Syntetická RNA, označovaná ako guide RNA (gRNA), slúži ako zameriavač, navádzač enzýmu Cas9 na vopred vytipované miesto v molekule DNA. Toto je len začiatok procesu editovania génov. Po prestrihnutí DNA enzýmom Cas9 nastúpia prirodzene sa v bunke vyskytujúce opravné enzýmy, ktorých ciel’om je scelit' prestrihnutú DNA (inak by došlo k smrti bunky). Existujú dva druhy takejto opravy DNA pomocou 
reparačných enzýmov. Jeden je nepresný a jeho výsledkom je, že prestrihnutú DNA síce scelí, ale za cenu, že bud' nejaký jej úsek bude v okolí miesta strihu chýbat', alebo naopak, nejaký kúsok DNA tam pridá navyše. Druhý opravný systém je schopný urobit' scelenie prestrihnutej DNA bez takýchto zmien. Ak sa mu však ,,podhodí“ vel'mi podobná DNA sekvencia, aká je $\mathrm{v}$ blízkosti miesta prestrihu, tak ju dokáže vymenit’ za pôvodnú. Ak napríklad sekvencia DNA v blízkosti miesta strihu je gén, ktorý obsahuje mutáciu, napríklad zámenu v jednom písmene genetickej abecedy, a „podhodená“ DNA sekvencia má na danom mieste správne písmeno, tak opravný systém vymení tieto sekvencie a v DNA sa fakticky opraví nesprávne písmeno genetickej abecedy za správne. Inými slovami, takáto technológia využívajúca CRISPR/Cas9 systém je schopná s presnostou jedného písmena z DNA vystrihovat' l'ubovol'ný genetický text, vkladat' do nej nový text, opravit' v nej „preklep“ (bodovú mutáciu). Analógia s editorskými funkciami cut and paste a replace / correct je zjavná - preto pomenovanie „editovanie génov“ 6 pre túto technológiu.

\section{Etické a spoločenské aspekty editovania génov}

$\mathrm{V}$ počiatkoch génového inžinierstva vedci začali v rámci biomedicínskeho výskumu skúšat' aj prenos l'udských génov vyvolávajúcich rakovinu (tzv. onkogénov) do baktérie Escherichia coli, ktorá je jednou z najoblúbenejších modelových baktérií v laboratóriách, ale tiež je bežnou súčast'ou l'udskej mikroflóry. Motívom bolo lepšie preskúmat' onkogény. Avšak vedci si uvedomili, že takýto výskum môže byt' vel'mi riskantný. Baktéria s l'udským onkogénom sa pol'ahky môže zo skúmavky dostat' do l'udského hrubého čreva, ktoré je jej prirodzeným prostredím a priniest' so sebou l'udský gén vyvolávajúci rakovinu. Obavy z takéhoto druhu experimentov viedli $\mathrm{k}$ tomu, že tých niekol'ko málo priekopníkov génového inžinierstva sa zl'aklo svojho vlastného objavu a navrhli v otvorenom liste (Berg et al. 1974) zaslanom do prestižneho vedeckého časopisu Science, aby vedci dočasne pozastavili (teda zaviedli tzv. moratórium) pokusy s rekombinantnou DNA (osobitne s tou, ked' sa kombinujú l'udské onkogény s DNA mikroorganizmov). Súčasne vedci sami zorganizovali konferenciu, na ktorej prediskutovali riziká spojené s používaním techník génového inžinierstva. Konferencia sa uskutočnila v roku 1975 v americkom Asilomare a stala sa historickým míl'nikom $\mathrm{v}$ dejinách manipulácie s DNA. Viedla $\mathrm{k}$ vytvoreniu bezpečnostných predpisov, ktorými vedci regulovali samých seba pri práci s rekombinantnou DNA.

\footnotetext{
${ }^{6}$ Niekedy sa tiež hovorí o editovaní genómu (angl. genome editing). Terminológia zatial' nie je ustálená, oba termíny, editovanie génov a editovanie genómu, sa momentálne považujú za ekvivalentné. Je možné, že v budúcnosti dôjde $\mathrm{k}$ ich rozlíšeniu, ked' editovanie génov bude označovat' editovanie na úrovni individuálnych génov a editovanie genómu bude označovat' aj editovanie na nadgénovej úrovni alebo editovanie mimogénovej DNA (ktorá mimochodom u človeka tvorí približne $98 \%$ celkovej DNA).
} 
Neskôr sa zapojili do procesu regulovania génového inžinierstva aj štátne inštitúcie a vytvorili celý systém štandardov biologickej bezpečnosti práce s rekombinantoiu DNA. Všeobecne sa má za to, že konferencia v Asilomare začala éru vzájomnej diskusie medzi biológmi a verejnost'ou o rizikách biologického vedeckého výskumu a jeho regulovania spoločnost'ou, tvorbou vedeckej politiky (science policy).

Avšak zvyčajne sa zabúda na to, že diskusia o kontrole biologického výskumu v súvislosti s možným ohrozením l'udskej existencie sa začala o niekol'ko rokov skôr. Ak sa nemýlime, vôbec prvý text tohto druhu bol publikovaný vo vedeckom časopise Science v roku 1970 a americký biológ Bernard Davis v ňom reaguje na návrhy v budúcnosti zakázat' akékol'vek genetické zásahy do l’udskej DNA vrátane zásahov opravujúcich genetické choroby (Davis 1970). Davis argumentoval, a to je z nášho pohl'adu zaujímavé, že je nezmyselné sa bavit' o týchto veciach, ked’že vedci nemajú ani zd'aleka také možnosti, aby mohli zasahovaním do DNA geneticky menit' l'udí.

Lenže populárna tlač už vtedy vykresl'ovala iný obraz o možnostiach genetiky. Pre nás je zaujímavý článok z roku 1971 v populárnom týždenníku TIME s príznačnou ilustráciou DNA, ktorá prekrýva ženské a mužské telo na titulnej strane, ${ }^{7}$ a s príznačným titulkom The New Genetics: Man into Superman. V článku sa tvrdí, že človek je na počiatku novej éry genetiky, ked' prevezme kontrolu nad svojou vlastnou evolúciou. Genetické poznanie sa tu prirovnáva $\mathrm{k}$ jedeniu ovocia zo zakázaného rajského stromu poznania. Preto treba, píše sa v článku, aby spoločnost' začala kontrolovat' genetický výskum. Z historického hl'adiska je pozoruhodné, že v tomto článku bol vôbec prvýkrát v médiách použitý termín „bioetika“ (Jonsen 1998, 27).

Bezpochyby obidva články upozornili na to, že sa naozaj deje niečo vážne. V roku 1972 dvaja americkí vedci vo vedeckom časopise Science prvýkrát publikovali koncepciu génovej terapie (Friedmann, Roblin 1972). V nej uvažovali o zatial' čisto teoretickej možnosti liečit' genetické ochorenia l'udí tým, že sa do buniek pacientov s poškodenými génmi za pomoci génového inžinierstva a rekombinantnej DNA vnesie zdravý gén, ktorý $v$ bunke funkčne zastúpi zmutovaný nefunkčný gén spôsobujúci dedičné ochorenie.

Trvalo d'alších osemnást' rokov, než sa teoretický koncept začal experimentálne testovat' na l'ud'och. Do dnešných dní sa uskutočnilo viac ako dvetisíc génových terapií. Vo všetkých týchto prípadoch ide o tzv. somatickú génovú terapiu, ked’ sa gény vnášajú do somatických buniek, a preto zmeny nie sú dedičné, neprenášajú sa na nasledujúce generácie.

Súčasne s prvými klinickými pokusmi génovej terapie sa začali formovat' etické zásady,ktoré súvisia $\mathrm{s}$ aplikovaním génového inžinierstva na l’udí (podrobnejšie

\footnotetext{
${ }^{7}$ Spomínanú ilustrácia z titulnej strany magazínu TIME je možné vidiet’ na: https://www.amazon.com/Time-Magazine-April-1971-Genetics/dp/B000LCTFB2
} 
k tomu Sýkora 2015, 2018). Počas troch desat'ročí vykonávania somatickej génovej terapie sa diskurz o etických aspektoch genetického zasahovania do l'udských génov viedol v znamení všeobecného konsenzu v otázke dvoch základných etických koordinát, dvoch etických línií. Prvou je „červená čiara“ oddel'ujúca od seba eticky prijatel’nú nededičnú intervenciu do génov somatických buniek a eticky (v mnohých štátoch vrátane Slovenska) aj legislatívne neprijatel'nú dedičnú intervenciu do génov línie zárodočných buniek. Druhou je „červená čiara“ oddel'ujúca od seba eticky prijatel'nú terapiu (vrátane genetickej) od eticky neprijatel'ného vylepšovania (vrátane genetického). Výsledkom prekríženia týchto dvoch čiar dostaneme štyri kvadranty, štyri eticky relevantné alternatívy.

Eticky najprijatel'nejšou je alternatíva somatickej génovej terapie (doteraz už viac ako dvetisíc klinických pokusov somatickej génovej terapie). Eticky menej prijatelnou je alternatíva somatického génového vylepšovania (napr. tzv. génový doping športovcov). Za ešte menej eticky prijatel'nú alternatívu sa pokladá terapia génov zárodočnej bunkovej línie a eticky úplne neprijatel’né je vylepšovanie génov zárodočnej bunkovej línie. A presne toho sa He Jiankui dopustil svojím experimentom. Ked' génovým editovaním odstránil z genómu dvoch l'udských jedincov gén CCR5, prekročil obidve červené etické línie, pretože aj ked' hovorí o zákroku s medicínskym ciel’om (prevencia proti HIV infekcii), nejde o terapiu, ale o dedičné genetické vylepšenie.

Kým hranica medzi zásahmi do somatických a zárodočných génov je ostrá a nie je problém identifikovat' jej prekročenie, etická línia medzi terapiou a vylepšením je neostrá a rozdiel nemusí byt' kvalitatívny, ale kvantitatívny, a kategorizácia je závislá od kontextu. Napríklad vylepšovanie kognitívnych schopností môže byt' terapiou, ale aj nemedicínskym vylepšením. Ak pôjde o vylepšenie jedinca s poškodenými kognitívnymi schopnostami (napr. trpiaceho Alzheimerovou chorobou), tak pôjde o terapiu, ak však pôjde o vylepšenie zdravého jedinca s normálnymi kognitívnymi schopnost’ami, potom pôjde zjavne o neterapeutické vylepšenie. Nehovoriac o tom, že sám referenčný bod toho, čo sa považuje za normálny zdravý stav a čo za vylepšenie, je pohyblivý a bude sa posúvat' v závislosti od masovosti terapie a vylepšovania. Dedičné vylepšovanie zárodočných génov, aké uskutočnil He Jiankui, prináša navyše otázky, ktoré smerujú priamo k problematike posthumanizmu.

\section{Kognitívne vylepšovanie človeka pomocou editovania génov}

Profesor Marvin Minsky (1927 - 2016) z MIT (Massachusetts Institute of Technology) zdôvodňoval nevyhnutnost' kognitívneho vylepšovania človeka tým, že mnohé problémy, ktoré ohrozujú l'udstvo, majú svoje korene v kognitívnych limitoch l'udskej mysle, a preto nebude možné tieto problémy riešit', pokial' sa nestaneme inteligentnejšími. Ako jeden z priekopníkov výskumu umelej inteligencie mal na mysli 
kognitívne vylepšovanie človeka pomocou počítačov a informačno-komunikačných technológií (IKT). Mnohí sú dnes presvedčení - pod vplyvom vel’mi známej knihy Singularita je blízko (Kurzweil 2005) z pera vynálezcu, futurológa a šéfa výskumu vo firme Google Raya Kurzweila -, že okolo roku 2045 bude výpočtová sila a kapacita počítačov na takej úrovni, že bude schopná fungovat' ako l'udská mysel' a človek bude môct' svoju mysel' skopírovat' do IKT média. Vznikne tak posthumánny človek. Tento zásadný prelom v existencii l'udstva označuje Kurzweil termínom singularita. Bez toho, aby sme sa púšt’ali do nepochybne filozoficky vel’mi zaujímavej otázky, či takáto transformácia človeka je vôbec možná (problematická je prinajmenšom identita transformovanej osoby - Odorčák 2015), dovolíme si súhlasit's kritikmi, že singularita rozhodne nebude otázkou najbližšej budúcnosti (napr. Allen, Greaves 2011). Nie preto, že by sa nesplnili jeho predikcie nárastu kapacity pamät’ových médií a výpočtovej rýchlosti, ale preto, že zd’aleka vývoj nanotechnológií nenapreduje takým tempom, aké je potrebné na to, aby bolo možné naskenovat' kompletný funkčný stav mozgu pre potreby jeho skopírovania. Zato pokrok v oblasti poznania vplyvu génov na kognitívne schopnosti, ako aj možnost' manipulácie s takýmito génmi napredujú tak rýchlo, že ako realistickejší scenár sa javí možnost', že zásadne kognitívne (a nielen kognitívne) vylepšeného človeka sa podarí realizovat' ovel'a skôr.

V roku 1999 americkí vedci publikovali výsledky pokusu, v ktorom geneticky manipulovali v podmienkach in vitro s embryami myší takým spôsobom, že zvýšili aktivitu jedného génu fungujúceho v nervových bunkách mozgu. Výsledkom boli geneticky modifikované myši, ktoré sa l’ahšie učili a lepšie si pamätali úlohy v špeciálnych kognitívnych testoch „myšacej inteligencie“. Táto genetická línia „super bystrých myšsi“ bola pomenovaná Doogie podl’a obl'úbenej postavy známeho amerického TV seriálu Doogie Howser, M. D. o detskom géniovi, ktorý vyštudoval univerzitu a v štrnástich rokoch sa stal lekárom. Spomenutá super bystrá myš bola vytvorená za pomoci technológie tzv. génového inžinierstva, ktorá bola vyvinutá v polovici sedemdesiatych rokov minulého storočia. Odborníkom, na rozdiel od laikov, však bolo jasné, že táto technológia nie je prakticky použitel’ná pre zložitejšie genetické manipulácie u evolučne vyspelejších organizmov, akými sú primáty vrátane človeka (Capeschi 2000). Takže obavy, že by sa pomocou génového inžinierstva mohli vytvorit' super bystrí l'udia, biológovia $\mathrm{v}$ tomto prípade stále považovali, podobne ako hore spomenutý B. Davis, za úplne nerealistické, za oblast' vedeckej fantastiky. To sa však zásadne mení v súčasnosti s príchodom technológie editovania génov.

Presuňme sa do súčasnosti - koncom marca 2019 bola publikovaná štúdia, ktorá opisuje výsledky experimentu, v ktorom čínski vedci voviedli do genetickej informácie raných embryí makakov l'udskú verziu génu MCPH1. Ide o jeden z mála doteraz známych génov, o ktorých vedci predpokladajú, že zohráva klúčovú úlohu v prena- 
tálnom vývoji l'udského mozgu. Ak je tento gén poškodený, dochádza k tzv. mikrocefálii ( $\mathrm{k}$ vývinu extrémne malého mozgu). $\mathrm{V}$ porovnaní s l'udskou verziou tohto génu sa verzia u ostatných primátov líši v šiestich písmenách genetickej abecedy. Vedcom sa podarilo úspešne voviest' l'udský gén medzi gény zárodočnej línie buniek, takže bol dedične d’alej prenášaný na potomkov prvej a druhej generácie. Testy ukázali, že makakovia s l'udským génom vykazovali lepšiu krátkodobú pamät' a kratší reakčný čas než geneticky nepozmenení jedinci (Jeffrey-Wilensky 2019).

Sotva niekoho prekvapí, že hned' po zverejnení týchto výsledkov si l'udia spomenuli na nedávny vedecko-fantastický film Zrodenie Planéty opíc (2011). V tomto filme počas testovania terapie na šimpanzici, ktorou by sa mala liečit' Alzheimerova choroba u l'udí (nie je vo filme bližšie spresnené, o aký typ terapie ide, ale zrejme má íst' o somatickú génovú terapiu s pomocou vírusového vektoru), dôjde náhodou k prenosu génu na šimpanzie embryo (vedec nevedel, že šimpanzica je gravidná), ktoré po narodení začne prejavovat' vysoko nadpriemernú (na pomery šimpanzov a aj mnohých l'udí) inteligenciu.

Z hl'adiska ciel'a tejto štúdie vyznie príznačne symbolicky porovnanie novej filmovej verzie s pôvodnou verziou Planéty opíc z roku 1968. Základná idea filmu zostáva $\mathrm{v}$ obidvoch filmoch tá istá: ako by vyzeral svet, $\mathrm{v}$ ktorom si l'udia a l'udoopice vymenia úlohy, ale filmy sa líšia vo vysvetlení, ako k tomu môže dôjst'. V Planéte opíc je to dôsledok prirodzenej evolúcie - l'udstvo je v dôsledku nukleárnej svetovej vojny takmer úplne zdecimované, a tým sa uvol’ní životný priestor (ako ked' vyhynuli dinosaury v dôsledku pádu asteroidu a uvol'nil sa priestor pre evolúciu cicavcov) pre pokračovanie prirodzenej evolúcie ludoopov, až dosiahnu stupeň inteligentných zvierat. Zmena úloh je pomalá. Technológia, ktorá je $\mathrm{v}$ hre, je fyzika - atómové bomby, cestovanie kozmonautov do budúcnosti. V Zrodeni planéty opíc je klúčovou vedou biológia s technológiami biomedicíny a zmena je rýchla - biologicky kognitívne vylepšený šimpanz, rýchle vymieranie ludí v dôsledku šírenia vírusovej infekcie (opičej chrípky, voči ktorej sú l'udoopice odolné, ale l'udia citliví). Navyše v novšej verzii nachádzame aj aktuálne bioetické posolstvo - vedecký výskum, medicínska technológia vyvinutá s nespochybnitel'ne etickým ciel’om, akým je liečit' pacientov, sa môže nepredvídatel'ne vymknút' $\mathrm{z}$ rúk a viest' $\mathrm{k}$ ohrozeniu existencie celého l'udstva.

Ponechajme bokom vel'mi zaujímavú otázku súvisiacu s etikou kognitívneho vylepšovania zvierat vrátane kognitívneho vylepšovania l'udoopíc. Akoby napríklad vyzerala odpoved' na otázku, či takto pol'udštené l'udoopice nemajú nárok na l'udské práva.

V tejto súvislosti je dôležité spomenút' reálnu možnost', že ku genetickému, a navyše dedičnému kognitívnemu vylepšeniu prostredníctvom editovania génov došlo v súčasnosti už aj u l'udí. Tým, že He Jiankui dvojičkám Lulu a Nana vystrihol 
gén CCR5, síce s ciel’om urobit' ich odolných voči HIV infekcii, nie je vylúčené, že ich tiež pravdepodobne aj kognitívne vylepšil. A v tomto prípade vylepšil aj ich budúce deti a deti ich detí, všetky nasledujúce generácie. Možné je takto usudzovat' na základe pokusov uskutočnených na myšiach, ktorým bol z genómu vystrihnutý gén CCR5. Takéto myši sa rýchlejšie naučili orientovat' v labyrinte a rýchlejšie si zapamätali bolestivé stimuly ako myši s génom CCR5. Podl'a neurovedca Kevina Foxa z Univerzity v Cardiffe, ktorý sa podiel’al na tomto výskume, odstránenie génu CCR5 zlepšilo kognitívne schopnosti myší o 30 až 60 \% (Cyranoski 2018). Keby sa to potvrdilo, znamenalo by to, že sa pravdepodobne uskutočnil prvý krok smerom k posthumánnemu človeku.

Samozrejme, voči takejto interpretácii možno očakávat' viacero námietok. Tou podstatnou, najmä zo strany humanitných a sociálnych vedcov bude, že takýto postoj reprezentuje typický genetický determinizmus. Pokial’ však termín genetický determinizmus nemá byt' len akousi ideologickou nálepkou, bude sa treba zo strany jeho užívatel'ov vyrovnat's ustavične narastajúcim empirickým poznaním potvrdzujúcim významný (hoci zd’aleka nie absolútny) vplyv génov na kognitívne l'udské schopnosti (Plomin and deFries 1998). K tomuto problému vzhl'adom na pojem l'udskej prirodzenosti sme sa podrobnejšie vyjadrili pred časom v inej našej publikácii (Sýkora 1999). A samozrejme, nesmieme zabúdat' na to, že v prípade kognitívnych schopností, ako napr. inteligencie, ide o vplyv vel'kého počtu génov (Plomin, von Stumm 2018), takže ich editovanie bude rádovo zložitejšie ako v spomínaných pokusoch s jedným génom. Avšak polygénny charakter znakov alebo vlastností nie je neprekonatel’nou prekážkou pre ich genetické upravovanie. Experimentálne už bola preukázaná schopnost' technológie CRISPR/ Cas9 simultánne editovat' viacero génov na rôznych miestach molekuly DNA.

\section{Editovanie génov a spoločnost'}

Vedecká, rovnako ako aj laická verejnost' zostala zaskočená He Jiankuiho pokusmi, ktorým sa dostalo širokej publicity v médiách (vrátane Slovenska) ${ }^{8}$ a ktoré vyvolali po celom svete vel'kú vlnu kritiky a všeobecného odmietnutia. Každopádne tieto pokusy, o ktorých sa spočiatku pochybovalo, či sa naozaj stali, ked’že chýbalo potvrdenie

\footnotetext{
${ }^{8}$ Napr. Otakar Horák: Čínsky vedec tvrdí, že po prvý raz v dejinách vylepšil genóm diet’ata, vedecká komunita je pobúrená. Uverejnené: Denník N, 27. 11. 2018, [https://dennikn.sk/1308108/cinskyvedec-tvrdi-ze-po-prvy-raz-v-dejinach-vylepsil-genom-dietata-vedecka-komunita-je-poburena/]; MLA: Imúnne voči HIV. VČ́ne sa údajne narodili prvé deti s upravenou DNA. Uverejnené: HN online, 27. 11. 2018, [https://science.hnonline.sk/medicina/1849418-imunne-voci-hiv-v-cine-saudajne-narodili-prve-deti-s-upravenou-dna]; Nina Haceková: Geneticky upravené deti sú 1 x na svete! Veda sa zbláznila, čo bude d’alej? Uverejnené: Pluska 29. 11. 2018, [http://www.pluska.sk/izdravie/deti/geneticky-upravene-deti-su-1-x-svete-veda-zblaznila-co-bude-dalej.html].
} 
z nezávislých zdrojov, ukázali, že scenáre vedeckej fantastiky o geneticky zmanipulovaných l'ud’och alebo zvieratách vrátane l’udoopíc sa stávajú realitou. Tým sa mení základné nastavenie diskurzu. Kým išlo len o vedecko-fantastické scenáre, filozofické, a najmä etické úvahy sa pokladali len za akési intelektuálne cvičenia. Teraz, ked’ sa genetické vylepšovanie ludí a zvierat vrátane ich kognitívnych schopností stáva realitou, diskusia o nich už nie je myšlienkovým experimentom, ale výzvou pre l'udstvo, s ktorou sa treba čo najskôr vyrovnat'. Eticky, filozoficky, politicky i legislatívne.

Pokusom He Jiankuia predchádzali prvé pokusy čínskych (v roku 2015) a amerických (v roku 2017) vedcov s editovaním génov v l’udských in vitro embryách bez snahy vložit' takto zmanipulované embryá do maternice. I to stačilo na to, aby sa vedci a bioetici po celom svete začali zaoberat' týmto problémom. V decembri 2015 bolo zorganizované prvé medzinárodné sympózium o editovaní l'udského genómu vo Washingtone D. C. a v roku 2018 druhé takéto sympózium v Hong Kongu. Na ňom neplánovane dostal priestor aj He Jiankui, aby oboznámil vedeckú komunitu i širšiu verejnost' s technickými detailmi vytvorenia prvých génovo editovaných detí. Od roku 2015 sa objavilo niekol'ko významných dokumentov i vedeckých štúdií, ktoré sa venovali rôznym aspektom editovania l'udského genómu. K najdôležitejším z nich patrí správa špeciálneho medzinárodného výboru, publikovaná pod názvom Human Genome Editing: Science, Ethics, and Governance (NASEM 2017), v ktorej sa prvýkrát, v kontraste s doterajším všeobecným postojom, pripúšta - po splnení vedeckých a etických podmienok - aj editovanie l'udských génov zárodočnej bunkovej línie s terapeutickým ciel’om (vylepšovanie je jednoznačne odmietnuté). Podobne správa renomovaného britského The Nuffield Council on Bioethics za určitých podmienok pripúšt’a dedičné editovanie l’udského genómu (Nuffield Council of Bioethics 2018). Obidve správy však potvrdzujú všeobecný konsenzus medzi vedcami, že v súčasnosti nie je technológia editovania génov dostatočne bezpečná, aby mohla byt' klinicky aplikovaná. Odignorovanie tohto postoja He Jiankuiom viedlo k spomínanému návrhu dočasného moratória zo strany vedcov, aj k urýchleniu hl'adania ciest (vytvorenie špeciálnej komisie) na úrovni Svetovej zdravotníckej organizácie (WHO) k celosvetovej regulácii dedičného editovania l’udských génov.

$\mathrm{Na}$ Slovensku v ostatných rokoch dobiehame dlhodobý deficit v oblasti informovania verejnosti o vedeckých poznatkoch, a preto môžeme súhlasit' so Szapuovou a Nuhlíčkom (2015), že aj u nás „v budúcnosti možno očakávat' zvýšený spoločenský dopyt po verejnom spolurozhodovaní o vedeckých otázkach“. Avšak ako upozorňujú, za predpokladu, že vedecká komunita aj tvorcovia politík budú mat' záujem udržat' dôveru slovenskej spoločnosti voči práci vedcov.

V tejto súvislosti treba uviest', že celoštátna Etická komisia Ministerstva zdravotníctva Slovenskej republiky (EK MZ SR) vel’mi promptne zareagovala na mediálne 
správy o Jiankuiho experimente a jednoznačne ho odsúdila ako neetický. Vo svojom stanovisku pripomenula dôležitost' informovania verejnosti o výsledkoch modernej vedy, ako aj o možných rizikách, a vyzýva vedecké aj vzdelávacie inštitúcie na Slovensku na spoluprácu:

Na dosiahnutie efektívneho postupu proti neetickému konaniu je však potrebné neustále zvyšovat' povedomie verejnosti o konkrétnych dôsledkoch vedeckého a technologického vývoja a jeho potenciálnych rizikách. EK MZ SR preto požaduje, aby orgány verejnej moci, ako aj vedecké a vzdelávacie inštitúcie v Slovenskej republike vytvárali podstatne širši priestor na vzdelávanie a odbornú diskusiu o etických témach $v$ oblasti biológie a medicíny. Len informovaná a eticky vzdelaná spoločnost' dokáže neetické konanie včas identifikovat' a postavit'sa mu na odpor (Etická komisia MZ SR, 2018).

Čo sa týka legislatívnej stránky, na Slovensku - podobne ako vo väčšine európskych krajín - by boli pokusy, aké uskutočnil He Jiankui, protiprávne. Slovensko sa svojím podpisom a ratifikovaním zaviazalo dodržiavat' medzinárodný dokument Rady Európy, známy ako Dohovor o l’udských právach a biomedicíne z roku 1997 (tzv. Oviedsky dohovor). Je to dodnes jediný medzinárodný bioetický dokument, ktorý nemá len deklaratívnu a odporúčaciu úlohu, ale je aj právne záväzný. Podla článku 13 Oviedskeho dohovoru je zakázané uskutočňovat' akékol'vek zásahy do l'udského genómu, ktoré by sa prenášali na potomkov. Výskum a nededičné zásahy do génov týmto zakázané nie sú. Pre Slovensko je tiež záväzné dodržiavat' Chartu základných práv Európskej únie, ktorá v článku 3, odstavec 2b zakazuje akékol'vek eugenické praktiky.

To však zd’aleka neznamená, že nemá zmysel o týchto veciach diskutovat'. Práve naopak. Spomínaná európska legislatíva bola prijímaná v situácii, ked’ sa cielené zásahy do l’udského genómu považovali za otázku vzdialenej budúcnosti a použitie technológií génového inžinierstva na človeka by bolo už len v dôsledku jej obrovskej nepresnosti a nespol'ahlivosti obrovským zdravotným rizikom a z vedeckého hl'adiska úplne nezmyselným krokom. Nástup technológií editovania génov však situáciu zásadne mení, pretože umožňuje cielené a vel'mi presné zasahovanie do l'udského genómu. Obavy z rizika nepresných zásahov (tzv. off targets) sú momentálne namieste, ale technológia editovania génov sa raketovým tempom zlepšuje a odborníci predpokladajú, že $\mathrm{v}$ dohl'adnom čase toto riziko bude znížené na medicínsky prijatel'nú úroveň. Preto sa vynára otázka, či by sa nemalo začat' diskutovat' o revízii Oviedskeho dohovoru s ohl'adom na jeho paušálny zákaz akéhokol'vek zasahovania do génov l'udskej zárodočnej línie a umožnit' zásahy do takýchto génov za účelom 
liečby dedičných ochorení (Sýkora, Caplan 2017). Protiargument, ktorý bol použitý proti takémuto návrhu, sa opiera o tvrdenie, že tým by bola ohrozená l'udská dôstojnost', ktorej ochrana je základným pilierom Oviedskeho dohovoru (Baylis, Ikemoto 2017). V takom prípade, by zákaz zasahovania do l'udských zárodočných génov nebol otázkou zdravotného rizika, a preto dočasný, ale otázkou najvyššieho etického princípu, a preto absolútny. Faktom však je, že jedným z ciel’ov Oviedskeho dohovoru (ako sa spomína $v$ jeho preambule) je, aby sa pokrok v biomedicíne používal nielen pre blaho jedinca a spoločnosti, ale aj v záujme blaha budúcich generácií a ochrany l'udského druhu ako takého. Eliminovanie dedičných ochorení prostredníctvom génovej terapie na úrovni génov zárodočnej bunkovej línie možno považovat' za spôsob, akým by sa zvyšovalo blaho budúcich generácií, a teda je plne v súlade so zámerom Oviedskeho dohovoru (Sýkora, Caplan 2017). Podobne argumentuje Raposo (2019), ked' tvrdí, že editovanie génov nie je porušením, ale potvrdením l'udskej dôstojnosti. Ba čo viac, objavil sa aj argument, že použitie l'udskej dôstojnosti ako argumentu proti pozmeňovaniu l'udského genómu v zárodočnej línii buniek je vlastne logickou chybou (de Miguel Beriain 2018).

Niet pochýb, že akékol'vek pozmeňovanie génov zárodočnej línie buniek, ktoré je súčasne dedičné, a preto sa bude prenášat na d’alšie generácie, prekračuje hranice tradičnej bioetiky, pretože sa netýka len úrovne individuálnych pacientov, ale nadindividuálnej úrovne a budúcnosti l'udského druhu. Zvýšená opatrnost' je tu nanajvýš potrebná. Medzi odborníkmi tiež panuje vzácna zhoda, že technológie dedičného editovania génov nie sú zatial' dostatočne bezpečné, aby boli klinicky použité, pretože napriek obrovskému technologickému progresu je stále vel'ká pravdepodobnost' výskytu neočakávaných a neželaných vedlajších účinkov, ohrozujúcich zdravie budúcich generácií. To však nie je dôvod, aby sme už dnes nediskutovali o podmienkach, za akých aj dedičné editovanie génov môže byt' použité, až raz bude z medicínskeho hl'adiska dostatočne bezpečné.

\section{Záver}

Problematika editovania génov sa netýka len (bio)etikov, ktorí sa už dávnejšie venujú tomuto problému, a netýka sa len tvorcov politík a legislatívy, ktorých ciel’om je racionálne regulovat' vedecký výskum a jeho dôsledky pre spoločnost', ale týka sa aj filozofov, ich koncepcií o l'udskej prirodzenosti. Na základe doterajšieho vývoja sa dá predpokladat', že editovanie génov (spolu s pokrokom v poznávaní fungovania l'udského genómu) prinesie v blízkej budúcnosti empirické poznanie, ktoré podrobí vel'kej výzve doterajšie filozofické koncepcie l'udskej prirodzenosti, opierajúce sa najmä o špekulácie, a to vrátane koncepcií o neexistencii ludskej prirodzenosti, respektíve o jej dejinnej, kultúrnej či sociálnej konštrukcii, ktorá postupne začala domi- 
novat' vo filozofii, antropológii a mnohých d’alších humanitných a spoločenských vedách dvadsiateho storočia s presahom do súčasnosti. Našt'astie, niektorí filozofi začínajú chápat' význam biotechnologických zásahov do l'udskej genetickej informácie pre filozoficko-antropologickú problematiku a v tejto súvislosti zdôrazňujú zmysel spochybňovaného pojmu l'udskej prirodzenosti (Zarka 2018). Pritom, ako sme na inom mieste zdôvodnili, pojem l'udskej prirodzenosti nemusí nadobúdat' zmysel len $\mathrm{v}$ rámci teologického, ale aj v rámci sekulárneho, naturalistického kontextu (Sýkora 2014). Navyše filozofická antropológia sa v budúcnosti pravdepodobne ocitne v podobnej situácii, v akej sa ocitla filozofická kozmológia po rozmachu astrofyziky, a pod tlakom empirického poznania bude musiet' zrevidovat' mnohé svoje koncepcie a názory na l'udskú prirodzenost', ktoré sa doteraz opierali najmä o špekulatívnu filozofickú tradíciu.

\section{Literatúra}

ALlEN, P. G., GREAVES, M. (2011): The Singularity Isn't Near. The MIT Technology Review (March / April), 7 - 65.

BAYLIS, F., IKEMOTO, L. (2017): The Council of Europe and the prohibition on human germline genome editing. EMBO Report, 18 (12), 2084 - 2085. [DOI:10.15252/embr.201745343]

BERG, P. et al. (1974): Potential Biohazards of Recombinant DNA Molecules. Science, 185 (4148), 303.

CAPPECCHI, M. R. (2000): Human Germline Gene Therapy: How and Why. In: Stock, G. Campbell, J. (eds.): Engineering the Human Genome. New York - Oxford: Oxford University Press, $31-42$.

CYRANOSKI D. (2018): Baby gene edits could affect a range of traits. Nature (Published online 12. 12. 2018). Dostupné na: https://www.nature.com/articles/d41586-018-07713-2). [DOI: 10.1038/d41586-018-07713-2]

DAVIS, B. D. (1970): Prospects for Genetic Intervention in Man. Science, 170 (3964), 1279 - 1283.

DE MIGUEL BERIAIN, I. (2018): Human dignity and gene editing: Using human dignity as an argument against modifying the human genome and germline is a logical fallacy. EMBO Report, 19 (10). Published online 21. 9. 2018. [https://doi.org/10.15252/embr.201846789]

DOUDNA, J. - STERNBERG, S. (2017): A Crack in Creation: Gene Editing and the Unthinkable Power to Control Evolution. Boston: Houghton Mifflin Harcourt.

ETICKÁ KOMISIA MZ SR (2018): Stanovisko Etickej komisie MZ SR k deklarovanému narodeniu geneticky modifikovaných detí. Bratislava 12. 12. 2018. Dostupné na: https://www.health.gov.sk/Clanok?eticka-komisia-stanovisko-20181214 (Navštívené: 24. 5. 2019).

FRIEDMANN, T., ROBLIN, R. (1972): Gene Therapy for Human Genetic Disease? Proposals for genetic manipulation in humans raise difficult scientific and ethical problems. Science, 175 (3), $949-955$.

JEFFREY-WILENSKY, J. (2019): Chinese scientists insert human brain gene into monkeys, spark ethical debate. NBC News Science (April 25). Dostupné na: https:/www.nbcnews.com/mach/ 
science/chinese-scientists-insert-human-brain-gene-monkeys-spark-ethical-debate-ncna998076

(Navštívené: 24. 5. 2019).

JONSEN, A. R. (1998): The birth of bioethics. New York: Oxford University Press.

KURZWEIL, R. (2005): Singularity is Near: When Humans Transcend Biology. New York - London: Viking Penguin.

LANDER et al. (2019): Adopt a moratorium on heritable genome editing. Nature, 567 (7747), 165 - 168. [doi: 10.1038/d41586-019-00726-5].

LEDFORD, H. (2015): CRISPR, The Disruptor. Nature, 522 (7554), 20 - 24. [DOI: 10.1038/ 522020a]

NASEM (2017): Human Genome Editing: Science, Ethics, and Governance. National Academies of Sciences, Engineering, and Medicine. Washington, DC: The National Academies Press.

NUFFIELD COUNCIL ON BIOETHICS (2018): Genome Editing and Human Reproduction: Social and Ethical Issues. London: Nuffield Council on Bioethics.

ODORČÁK, J. (2015): Kopírovanie zabíja identitu osoby. Filozofia, 70 (5), 367 - 377.

PARRINGTON, J. (2016): Redesigning Life: How Genome Editing will Transform the World. Oxford: Oxford University Press.

PLOMIN, R., DeFRIES, J. (1998): The Genetics of Cognitive Abilities and Disabilities. Scientific American, 278 (5), 62 - 69.

PLOMIN, R., von STUMM S. (2018): The new genetics of intelligence. Nature Reviews Genetics, 19 (3), $148-159$.

RAPOSO, V. L. (2019): Gene Editing, the Mystic Threat to Human Dignity. Journal of Bioethical Inquiry. Published online 18. 3. 2019. Dostupné na: https://doi.org/10.1007/s11673-01909906-4 (Navštívené: 24. 5. 2019).

REGALADO A. (2018): EXCLUSIVE: Chinese scientists are creating CRISPR babies. The MIT Technology Review (online 25. 11. 2018). Dostupné na: https://www.technologyreview. com/ s/612458/exclusive-chinese-scientists-are-creating-crispr-babies/ (Navštívené: 24. 5. 2019).

SÝKORA, P. (1999): Bojí sa sociológia biológie? Sociológia, 31 (4), 375 - 396.

SÝKORA, P., MATĚJKOVÁ, E. (2011): Kognitívne vylepšovanie človeka, evolúcia a etika. In: Kelemen, J. et al. (eds.): Kognice a umélý život. Opava: Slezská univerzita v Opavě, $255-267$.

SÝKORA, P. (2014): Kritika teologicko-teleologickej koncepcie l’udskej prirodzenosti ako dôvodu odmietnutia transhumanizmu. Filozofia, 69 (6), 514 - 525.

SÝKORA, P. (2015): Etika biotechnologických zásahov do l'udského genómu: Argumenty rizikovosti a zničenia l'udskej prirodzenosti. Filozofia, 70 (5), 329 - 342.

SÝKORA, P., CAPLAN, A. (2017): Germline gene therapy is compatible with human dignity. EMBO Report, 18 (12), 2086. [doi: 10.15252/embr.201745378]

SÝKORA, P., CAPLAN, A. (2017): The Council of Europe should not reaffirm the ban on germline genome editing in humans. EMBO Report, 18 (11), 1871 - 1872. [doi: 10.15252/embr. 201745246]

SÝKORA, P. (2018): Germline gene therapy in the era of precise genome editing: How far should we go? In: Soniewicka, M. (ed.): The Ethics of Reproductive Genetics - Between Utility, Principles, and Virtues. Series: Philosophy and Medicine (Book 128). Heidelberg - New York London: Springer. 
SZAPUOVÁ, M., NUHLÍČEK, M. (2015): Veda a verejnost': Premeny spôsobov tvorby poznania a ich vzt’ahovania k verejnosti. In: Plašienková, Z. (ed.): Bioetické výzvy a súčasnost'. Bratislava: Stimul.

TAYLOR, G. R. (1971, orig. 1968): Biologická časovaná bomba. Bratislava: Slovenský spisovatel'.

ZARKA, Y. Ch. (2018): Má ešte pojem l’udská prirodzenost' zmysel? Filozofia, 73 (10), 777 - 789.

Táto práca bola podporená Agentúrou na podporu výskumu a vývoja na základe Zmluvy č. APVV -17-0064 v rámci projektu Analýza multidimenzionálnej podoby trans- a posthumanizmu.

Peter Sýkora

Katedra filozofie a aplikovanej filozofie

Centrum pre bioetiku

Filozofická fakulta Univerzity sv. Cyrila a Metoda

Nám. J. Herdu 2

91701 Trnava

Slovenská republika

e-mail: petersykora111@gmail.com

ORCID ID: https://orcid.org/0000-0002-1870-4626 